\title{
Exposure to violence in incarcerated youth from the city of São Paulo
}

\section{Exposição à violência entre jovens da cidade de São Paulo em privação de liberdade}

\author{
Susan Huculak, ${ }^{1}$ John D. McLennan, ${ }^{2}$ Isabel A. S. Bordin ${ }^{3}$ \\ 1 Department of Community Health Sciences, Faculty of Medicine, University of Calgary, Calgary, Alberta, Canada \\ 2 Departments of Community Health Sciences, Psychiatry and Pediatrics, Faculty of Medicine, University of Calgary, Calgary, Alberta, Canada \\ 3 Departamento de Psiquiatria, Universidade Federal de São Paulo (UNIFESP), São Paulo, SP, Brazil
}

\begin{abstract}
Objective: This study aimed to determine the extent of exposure to community violence among delinquent Brazilian youth in the 12-month period prior to their incarceration and to identify factors associated with this exposure. Method: With an oversampling of girls, a cross-section of youth under 18 years of age from juvenile detention units in the city of São Paulo, Brazil completed a structured interview. Key items related to exposure to violence (witnessed and experienced) were drawn from the Social and Health Assessment questionnaire to cover the 12-month period prior to incarceration. Results: Participants ( $\mathrm{n}=325,89 \%$ boys) reported high rates of exposure to violence with largely similar levels for boys and girls. Being threatened with physical harm, being beaten or mugged and/ or shot at were the most common forms of violence experienced. After controlling for demographic and family variables, the fact of having peers involved in risk behavior, easy access to guns and previous involvement with the justice system were associated with witnessed violence; whereas having slept on the street was the only variable associated with experienced violence. Conclusion: This group of youth was exposed to high levels of violence and other adverse experiences. Future research should examine the effectiveness of strategies aimed at reducing the exposure to violence of high-risk youth.
\end{abstract}

Descriptors: Violence; Adolescent; Juvenile delinquency; Brazil; Human rights

\begin{abstract}
Resumo
Objetivo: Esse estudo procurou determinar a extensão da exposição à violência na comunidade entre jovens brasileiros delinquentes nos 12 meses que antecederam sua privação de liberdade e identificar fatores associados a essa exposição. Método: Um corte transversal de menores de 18 anos internados em unidades da Fundação Casalex-FEBEM na cidade de São Paulo, Brasil (com meninas superamostradas) participou de entrevista estruturada. Itenschave sobre exposição à violência (testemunhada e vivenciada) foram retirados do questionário Social and Health Assessment para cobrir o periodo de 12 meses anterior à internação. Resultados: Os participantes ( $n=325,89 \%$ meninos) referiram altas taxas de exposição à violência, taxas estas muito similares entre meninos e meninas. Ter sofrido ameaças de lesäo fisica, ter sido espancado ou assaltado elou baleado foram as formas mais comuns de violência vivenciada. Após controlar por fatores sociodemográficos e familiares, o relacionamento com jovens envolvidos em comportamentos de risco, o fácil acesso a armas de fogo e a passagem prévia pela Justiça estiveram associados à violência testemunhada, enquanto ter dormido na rua foi o único fator associado à violência vivenciada. Conclusão: Esse grupo de jovens foi exposto a altos niveis de violência e a outras experiências adversas. Pesquisas futuras devem examinar a efetividade de estratégias que visem reduzir a exposição à violência entre jovens de alto risco.
\end{abstract}

Descritores: Violência; Adolescência; Delinquência juvenil; Brasil; Direitos humanos

\section{Introduction}

Exposure to violence represents a violation under the United Nations Convention on the Rights of the Child. ${ }^{1}$ In addition to identifying protection and care factors for the well-being of children and youth in the Convention, there are explicit articles addressing violence both at home and in the general society. In addition to acknowledging the violation of these rights, studies show that children and youth exposed to violence are at a heightened risk for several negative outcomes including violent or aggressive behavior and delinquency, ${ }^{2-4}$ mental health problems such as post-traumatic stress disorder, substance use, anxiety and depression, ${ }^{2,5-7}$ academic problems, ${ }^{8}$ cognitive impairments, ${ }^{9}$ and criminal offenses in early adulthood. ${ }^{10}$

There are a number of reports on exposure to violence of typical and high-risk youth in high-income countries, particularly the
Submitted: April 27, 2010

Accepted: September 27, 2010
Correspondence

Susan Huculak

3rd Floor, TRW Building, 3280

Hospital Drive NW, Calgary, Alberta, CANADA T2N $4 Z 6$

Phone: (403) 220-4295 Fax (403) 270-7307

Email: huculaks@ucalgary.ca 
United States, ${ }^{11-16}$ however, much less information is available on the extent and predictors of youth exposure to community violence in low-and middle-income countries. Recently, a retrospective report of child sexual abuse in El Salvador has flagged the importance of coordinating efforts at the state and community levels to strengthen the realization of the rights of these children and youth. ${ }^{17}$ High-risk youth (e.g., delinquent youth) should be afforded particular priority as they may be exposed to higher rates of violence than other youth. ${ }^{18}$ For example, one study in the United States found delinquent youth to have significantly higher levels of witnessed and directly experienced community violence as compared to inner-city youth attending high school. ${ }^{18}$ Likewise, at least in the United States, delinquent youth may also experience higher rates of traumatic violence as compared with their community counterparts. ${ }^{19}$

Among the first countries to ratify the Convention on the Rights of the Child and home to one of the most progressive legislations on the rights of children, ${ }^{20}$ Brazil may be posited to be among the leaders in protecting the rights of its children and youth. However, there have been several reports on the violation of the rights of youth in Brazil, and particularly of those who are especially marginalized. ${ }^{21}$ For example, among incarcerated youth in the São Paulo detention system, an Amnesty International report ${ }^{22}$ highlighted concerns of overcrowding, physical abuse, understaffing and lack of staff training, unsanitary conditions, and inappropriate transfers to adult prison facilities. Even in the general community, Brazilian youth can be exposed to particularly high levels of violence. In a sample of 1,193 young people attending the eighth grade in Porto Alegre, Brazil, 28\% reported having been mugged, $25 \%$ chased by gangs, and 20\% threatened with physical harm. In the city of São Paulo, eight-graders reported having used knives $(5.3 \%)$ and guns $(3.8 \%)$ in fights occurred in the last 30 days. $^{23}$

Despite these patterns, little systematic information can be found on exposure to violence of youth who have been incarcerated in Brazil, a potentially very high-risk group. The aims of this study were (1) to determine the prevalence of witnessed and experienced violence in incarcerated youth from the city of São Paulo, Brazil; (2) to examine whether this prevalence varies according to gender; and (3) to determine whether potential risk factors are associated with exposure to violence.

\section{Method}

\section{Setting and sample}

At the planning stage of the study's sampling, the agency that manages juvenile detention units in the state of São Paulo (Fundação do Bem-Estar do Menor - FEBEM, now Fundação Casa) provided information on the number of units operating within the greater metropolitan area of the city of São Paulo. All girls were housed within two free-standing units, both of which were included in the sample. Boys were housed in either free-standing units or units within large compounds. Sampling for boys was stratified across these two unit types to ensure the inclusion of freestanding units. Two of the five free-standing units for boys were randomly selected. The compound units for boys each contained multiple individual units. Of the five total compounds, two were not eligible for inclusion as they were deemed unsafe for the research staff to enter given their history of violent riots. Two of the remaining three compounds were selected randomly, within which seven individual units were selected randomly. An eighth individual unit, which housed the youngest boys, was added to ensure the inclusion of a full range of youth. Additional details on the sampling methods used are reported elsewhere. ${ }^{24}$ It was not possible to reweight the sample to generate findings that would estimate violence prevalence for the full source population given the lack of information on the number of youth in each unit

Youth within the selected units had to fulfill the following inclusion criteria to be eligible: (1) age between 12 and 17 years, (2) reside in the city of São Paulo immediately before incarceration, (3) being placed in a locked facility on a full-time basis at the time of recruitment, and (4) "Awaiting Judicial Decision" status (a report filed with the judge that commences the process for deciding on the release date for the youth).

\section{Procedures}

Youth were interviewed face-to-face using a structured questionnaire between April and October, 2004. The study was approved by the ethics committee of the Universidade Federal de São Paulo. In addition, the study was approved by FEBEM officers and by a judge responsible for the incarcerated youth. The youth were informed of the voluntary nature of the study and only those who assented to participate were included in the study.

\section{Measures}

1) Exposure to violence (dependent variables)

The full questionnaire contained several sections taken from the Social and Health Assessment (SAHA) questionnaire. ${ }^{25}$ These included the section on witnessed and experienced violence for which findings have been reported in other populations. ${ }^{3,26}$ Six items evaluating several types of exposure to violence (being beaten/mugged, threatened with serious physical harm, seriously wounded by violence, shot at with a gun, chased by gangs/ individuals, attacked/stabbed with a knife) were asked twice (witnessed and experienced). The scale included five Likert-type responses: "none" (0), "1-2 times" (1), "3-5 times" (2), "6-9 times" (3), "10 or more times" (4). The youth were asked to report on the 12 -month period prior to their current incarceration. Total index scores for witnessed violence and experienced violence were produced through summation of the values assigned to each individual item (i.e., 0 to 4 ). Cronbach's alpha $(\alpha)$ for the witnessed violence and experienced violence scales were 0.80 and 0.63 , respectively. For reporting on exposure to violence, individual items were dichotomized between 0 and $\geq 1$ exposures. Further detail about these variables is available elsewhere. ${ }^{27}$

2) Independent variables

The Brazilian Economic Classification Criteria ${ }^{28}$ was used to classify the participants' economic status. The instrument is based on the quantity of household goods, the educational level 
of the head of the household, and the number of home employees working at least five days a week. The total score is associated with one of five categories between "A" (high) and "E" (low). A/B and $\mathrm{D} / \mathrm{E}$ were collapsed to increase the sample size per category.

Several questions were drawn from the Drug Use Screening Inventory - Revised (DUSI-R), an instrument for youth that inquires about the types and extent of involvement with substance use and consequences of drug or alcohol problems, such as family dysfunctions or academic problems. ${ }^{29}$ A Brazilian Portuguese version of this instrument, which was shown to be psychometrically sound, ${ }^{30}$ was used. From the drug use frequency section of this instrument, a report of use of any illicit drug for 10 or more times in the month preceding incarceration was coded as "heavy drug use". The response pattern to 14 questions on family adjustment from the DUSI-R (e.g., "Were your parents or guardians unaware of your likes and dislikes?", "Has a member of your family ever been arrested?") was used to create the Family Adjustment Problem Index (FAPI). The scale had an internal consistency of 0.63 (Cronbach's alpha). Single items on past involvement with gangs and alcohol use by a family member "causing problems at home, at work, or with friends" were also extracted from other sections of this instrument.

The extent to which the youth's peers engaged in risk behaviors was assessed with items drawn from the SAHA. The resulting scale (Peers Engaged in Risk Behaviors - PERB) includes nine items describing a variety of behaviors (e.g. dropping out of school, involvement in drug traffic) scored from one (no friends engaged in the behavior) to four (most or all friends engaged). A $10^{\text {th }}$ item from the original scale related to smoking was excluded to improve the psychometric performance of the scale. Cronbach's alpha was 0.85 for this sample.

Several questions were specifically developed for the study, including whether the youth had (1) slept on the street, (2) had previously been under a juvenile justice measure, and (3) whether the youth perceived that obtaining a gun in their neighborhood was easy. The number of years behind in school was also determined.

\section{Analysis}

Chi-square and Fisher's exact tests were used to determine the relationship between exposure to violence and gender. Spearman correlations, Student's $t$-tests, and analyses of variance (ANOVA) were used to determine the bivariate relationship between exposure to violence and variables hypothesized to be associated with witnessed and experienced violence. Multiple hierarchical regression analyses were run to determine whether any of the hypothesized variables were associated with community violence scores within the sample. Hypothesized risk factors with significant bivariate relationships $(\mathrm{p}<0.05)$ with either witnessed or experienced community violence were used in the multivariate analysis. Potential associated variables that were conceptually similar were grouped in hierarchical block entries to estimate their relationship with exposure to violence. This approach allows the evaluation of the extent of the contribution, if any, accounted for by each block (e.g. family variables) as well as any unique contributions accounted for by individual variables. Separate regression analyses were completed for witnessed and experienced violence to determine if there were any unique associated variables in each case.

\section{Results}

Participants ( $\mathrm{n}=325,89 \%$ boys) were aged $12-17$ years (mean $=15.9, \mathrm{SD}=1.1)$. Boys and girls were similar across a variety of demographic and risk factors hypothesized to be linked with exposure to violence in this population (Table 1). Significantly more girls than boys reported having slept on the street $\left(\chi^{2}=7.1, \mathrm{p}<0.01\right)$ and were more frequently connected with peers engaged in risk behaviors $(t=2.0, d f=294, p<0.05)$.

\section{Exposure to violence}

In this sample, $94 \%$ of the girls and $96 \%$ of the boys witnessed and $61 \%$ of the girls and $60 \%$ of the boys experienced at least one type of violence identified in the SAHA in the year prior to incarceration (Table 2). Seeing or being a beating or mugging

Table 1 - Demographic characteristics and risk factors for incarcerated youth by gender

\begin{tabular}{|c|c|c|}
\hline & $\begin{array}{c}\text { Girls }(n=36) \\
\%(n)\end{array}$ & $\begin{array}{c}\text { Boys }(n=289) \\
\%(n)\end{array}$ \\
\hline \multicolumn{3}{|l|}{$\begin{array}{l}\text { DEMOGRAPHIC } \\
\text { CHARACTERISTICS }\end{array}$} \\
\hline \multicolumn{3}{|l|}{ Age (years) } \\
\hline $12-14$ & $13.9(5)$ & $14.5(42)$ \\
\hline $15-17$ & $86.1(31)$ & $85.5(247)$ \\
\hline \multicolumn{3}{|l|}{ Economic status } \\
\hline A/B (high) & $11.1(4)$ & $16.9(49)$ \\
\hline C & $47.2(17)$ & $52.2(151)$ \\
\hline $\mathrm{D} / \mathrm{E}$ (low) & $38.9(14)$ & $30.4(88)$ \\
\hline \multicolumn{3}{|l|}{ Living arrangement } \\
\hline Biological mother and father & $22.2(8)$ & $31.5(91)$ \\
\hline Biological mother, not father & $44.4(16)$ & $47.4(137)$ \\
\hline $\begin{array}{l}\text { Not living with biological } \\
\text { mother }\end{array}$ & $33.3(12)$ & $21.1(61)$ \\
\hline RISK FACTORS & $\%(n)$ & $\%(n)$ \\
\hline Heavy drug use by youth & $47.2(17)$ & $38.8(112)$ \\
\hline $\begin{array}{l}\text { Family member has alcohol- } \\
\text { related problems }\end{array}$ & $33.3(12)$ & $25.3(73)$ \\
\hline $\begin{array}{l}\text { Previous juvenile justice } \\
\text { measure(s) }\end{array}$ & $58.3(21)$ & $44.3(128)$ \\
\hline $\begin{array}{l}\text { Easy access to guns in } \\
\text { neighborhood }\end{array}$ & $41.7(15)$ & $47.4(137)$ \\
\hline Gang involvement & $8.3(3)$ & $5.9(17)$ \\
\hline \multirow[t]{2}{*}{ Having slept on the street } & $50.0(18)^{\star \star}$ & $27.0(78)$ \\
\hline & Mean (SD) & Mean (SD) \\
\hline $\begin{array}{l}\text { Number of people in the } \\
\text { household }\end{array}$ & $6.2(2.0)$ & $5.5(2.0)$ \\
\hline $\begin{array}{l}\text { Family Adjustment } \\
\text { Problems Index }\end{array}$ & $28.6(17.3)$ & $23.2(16.3)$ \\
\hline $\begin{array}{l}\text { Peers Engaged in Risk } \\
\text { Behaviors }\end{array}$ & $26.4(6.5)^{\star}$ & $24.1(6.2)$ \\
\hline $\begin{array}{l}\text { Number of years behind in } \\
\text { school }\end{array}$ & $3.6(1.7)$ & $3.8(1.9)$ \\
\hline
\end{tabular}

${ }^{*} p<0.05,{ }^{* *} p<0.01$ 
Table 2 - Frequency distribution of different types of exposure to violence among incarcerated youth by gender

\begin{tabular}{|c|c|c|}
\hline & $\begin{array}{c}\text { Girls }(n=36) \\
\%(n)\end{array}$ & $\begin{array}{c}\text { Boys }(n=289) \\
\%(n)\end{array}$ \\
\hline \multicolumn{3}{|l|}{ EXPOSURE TO VIOLENCE * } \\
\hline \multicolumn{3}{|l|}{ Being beaten or mugged } \\
\hline Witnessed & $83.3(30)$ & $87.5(253)$ \\
\hline Experienced & $41.7(15)$ & $30.8(89)$ \\
\hline \multicolumn{3}{|l|}{$\begin{array}{l}\text { Being threatened with } \\
\text { serious physical harm }\end{array}$} \\
\hline Witnessed & $75.0(27)$ & $72.7(210)$ \\
\hline Experienced & $27.8(10)$ & $34.3(99)$ \\
\hline \multicolumn{3}{|l|}{$\begin{array}{l}\text { Being seriously wounded } \\
\text { by violence }\end{array}$} \\
\hline Witnessed & $58.3(21)$ & $66.4(192)$ \\
\hline Experienced & $8.3(3)$ & $15.6(45)$ \\
\hline \multicolumn{3}{|l|}{$\begin{array}{l}\text { Having shot or been shot at } \\
\text { with a gun }\end{array}$} \\
\hline Witnessed & $72.2(26)$ & $64.7(187)$ \\
\hline Experienced & $8.3(3)$ & $24.2(70)$ \\
\hline \multicolumn{3}{|l|}{$\begin{array}{l}\text { Having been chased by } \\
\text { gangs or individuals }\end{array}$} \\
\hline Witnessed & $33.3(12)$ & $42.2(122)$ \\
\hline Experienced & $5.6(2)$ & $15.9(46)$ \\
\hline \multicolumn{3}{|l|}{$\begin{array}{l}\text { Having been attacked or } \\
\text { stabbed with a knife }\end{array}$} \\
\hline Witnessed & $27.8(10)$ & $33.2(96)$ \\
\hline Experienced & $13.9(5)$ & $5.5(16)$ \\
\hline \multicolumn{3}{|l|}{ Any of the above } \\
\hline Witnessed & $94.4(34)$ & $95.8(277)$ \\
\hline Experienced & $61.1(22)$ & $59.9(173)$ \\
\hline \multicolumn{3}{|l|}{ Number of above types } \\
\hline \multicolumn{3}{|l|}{ - 1 type only } \\
\hline Witnessed & $8.3(3)$ & $6.9(20)$ \\
\hline Experienced & $33.3(12)$ & $22.4(65)$ \\
\hline \multicolumn{3}{|l|}{ - 2-3 types } \\
\hline Witnessed & $30.5(11)$ & $33.2(96)$ \\
\hline Experienced & $25.0(9)$ & $29.1(84)$ \\
\hline \multicolumn{3}{|l|}{-4 or more types } \\
\hline Witnessed & $55.6(20)$ & $55.7(161)$ \\
\hline Experienced & $2.8(1)$ & $7.9(23)$ \\
\hline OTHER ABUSES & $\%(n)$ & $\%(n)$ \\
\hline Sexual abuse (lifetime) & $19.4(7)^{\star \star}$ & $3.5(10)$ \\
\hline Physical abuse (lifetime) & $47.2(17)$ & $48.1(139)$ \\
\hline Beating by police (at arrest) & $63.9(23)$ & $74.7(216)$ \\
\hline
\end{tabular}

victim or being threatened with serious harm were the violence types that received the most endorsements from both boys and girls. In addition, $14 \%$ of girls and $10 \%$ of boys reported having witnessed at least three different types of violence at a 'high frequency' level (defined here as six or more incidences), and $17 \%$ of girls and $6 \%$ of boys reported having experienced one or more types of violence at a 'high frequency' level. Sexual abuse was more common among girls $(\mathrm{p}<0.005)$.

\section{Correlates of exposure to community violence}

Results of the bivariate analysis are summarized in Table 3. Given the bivariate association between age and both witnessed and experienced violence, age was entered into the first block for the multivariate analysis as the single demographic control. Most of the measured risk factors demonstrated statistically significant bivariate relationships with both witnessed and experienced violence exposure in the expected direction (Table 3).

\section{Witnessed violence}

Upon examining the possible independent associations of witnessed violence, the demographic control variable (age) explained a small but significant amount of the variance in the criterion $\left(\mathrm{F}_{(1,280)}=5.64, \mathrm{p}<0.05\right)$. After controlling for age, the risk factors as a group explained an additional $30.6 \%$ of the variability in witnessed violence outcome scores. The block comprising variables associated with family adjustment problems made the greatest overall contribution among the various risk factor blocks, explaining $16.2 \%$ of the variance $\left(\mathrm{F}_{(3,278)}=20.55, \mathrm{p}<0.001\right)$. The remaining blocks made significant, although more modest, contributions, including peer group/neighborhood variables, adverse experiences (having slept on the street) and youth behavior problems. Additional risk factors that made unique contributions to the variance in witnessed violence within the final model were involvement with high-risk peers $(t=4.0, p<0.001)$, easy access to guns $(\mathrm{t}=2.5, \mathrm{p}<0.05)$, and having had previous involvement with the juvenile justice system $(t=2.3, p<0.05)$. Gang involvement, alcohol-related problems in the family, and heavy drug use by the youth, despite having a bivariate relationship with witnessed violence, proved redundant with other variables that were added to the final model.

\section{Experienced violence}

Using experienced violence as the dependent variable, the various risk factors as a group accounted for $18.6 \%$ of the variance in outcome scores. The block including family difficulties contributed to the largest gain in variance, with $11.5 \%\left(\mathrm{~F}_{(2,278)}=19.93, \mathrm{p}<\right.$ $0.001)$. The blocks with peer group/neighborhood and adverse experience variables also made significant, although less substantial, contributions to the variance $\left(4.5 \%, \mathrm{~F}_{(5,275)}=11.28, \mathrm{p}<0.001\right.$, and $2.6 \%, \mathrm{~F}_{(6,274)}=11.15, \mathrm{p}<0.001$, respectively). Having slept on the street was also a modestly significant contributor $(t=2.3$, $\mathrm{p}<0.05)$. Age, high-risk peers, easy access to guns, behaviorrelated variables, and number of years behind in school were only redundant explanatory factors within the model.

\section{Discussion}

Nearly all participants had witnessed and over half had been victimized by violence within their communities. Comparing these results to the existing literature is problematic as most studies did not use the same or similar instruments for measuring exposure rates. For example, one study involving a sample of 1,193 eighthgrade public-school students from Porto Alegre in the south of Brazil noted exceptionally high rates of both witnessed (98\%) 
Table 3 - Bivariate association between hypothesized correlates and two exposure to community violence scales: witnessed and experienced

\begin{tabular}{|c|c|c|}
\hline & $\begin{array}{l}\text { Witnessed } \\
\text { violence } \\
\text { Mean (SD) }\end{array}$ & $\begin{array}{c}\text { Experienced violence } \\
\text { Mean (SD) }\end{array}$ \\
\hline \multicolumn{3}{|l|}{$\begin{array}{l}\text { DEMOGRAPHIC } \\
\text { CHARACTERISTICS } \\
\text { Gender }\end{array}$} \\
\hline Male & $7.8(5.5)$ & $1.9(2.6)$ \\
\hline Female & $7.6(5.5)$ & $2.1(3.1)$ \\
\hline \multicolumn{3}{|l|}{ Age (years) } \\
\hline $12-14$ & $9.8(6.3)^{*}$ & $2.9(3.4)^{\star}$ \\
\hline $15-17$ & $7.5(5.2)$ & $1.7(2.4)$ \\
\hline \multicolumn{3}{|l|}{ Economic status } \\
\hline A/B (high) & $7.6(5.6)$ & $2.0(2.6)$ \\
\hline $\mathrm{C}$ & $7.7(5.2)$ & $1.9(2.6)$ \\
\hline D/E (low) & $8.0(5.9)$ & $1.8(2.6)$ \\
\hline \multicolumn{3}{|l|}{ Living arrangement } \\
\hline $\begin{array}{l}\text { Biological mother and } \\
\text { father }\end{array}$ & $8.0(5.7)$ & $1.6(2.4)$ \\
\hline Biological mother, not & $7.8(5.5)$ & $1.9(2.5)$ \\
\hline $\begin{array}{l}\text { father } \\
\text { Not living with biological } \\
\text { mother }\end{array}$ & $7.6(5.2)$ & $2.3(3.0)$ \\
\hline OTHER RISK FACTORS & Mean (SD) & Mean (SD) \\
\hline \multicolumn{3}{|l|}{ Substance use } \\
\hline Heavy drug use & $9.9(5.5)^{\star \star \star}$ & $2.8(3.1)^{\star \star \star}$ \\
\hline $\begin{array}{l}\text { Not heavy drug use } \\
\text { - Family member }\end{array}$ & $6.5(5.0)$ & $1.3(2.0)$ \\
\hline Alcohol-related problems & $9.1(5.4)^{\star}$ & $2.4(2.8)$ \\
\hline $\begin{array}{l}\text { No alcohol-related } \\
\text { problems }\end{array}$ & $7.4(5.5)$ & $1.7(2.5)$ \\
\hline \multicolumn{3}{|l|}{$\begin{array}{l}\text { Previous juvenile justice } \\
\text { measure(s) }\end{array}$} \\
\hline $\begin{array}{l}\text { Has had previous } \\
\text { measures }\end{array}$ & $9.0(5.9)^{\star \star \star}$ & $2.3(2.9)^{\star \star}$ \\
\hline $\begin{array}{l}\text { Has not had previous } \\
\text { measures }\end{array}$ & $6.8(4.8)$ & $1.5(2.3)$ \\
\hline \multicolumn{3}{|l|}{$\begin{array}{l}\text { Access to guns in } \\
\text { neighborhood }\end{array}$} \\
\hline Easy access to guns & $9.4(5.6)^{* * *}$ & $2.3(2.9)^{\star \star}$ \\
\hline Not easy access to guns & $6.4(5.0)$ & $1.4(2.2)$ \\
\hline \multicolumn{3}{|l|}{ Gang involvement } \\
\hline Previous involvement & $10.7(5.7)^{*}$ & $3.8(3.7)^{*}$ \\
\hline No previous involvement & $7.6(5.4)$ & $1.8(2.5)$ \\
\hline \multicolumn{3}{|l|}{ Sleeping on the street } \\
\hline Has slept on the street & $10.0(5.8)^{\star \star \star}$ & $3.0(3.2)^{\star \star \star}$ \\
\hline \multirow{2}{*}{$\begin{array}{l}\text { Has never slept on the } \\
\text { street }\end{array}$} & $6.9(5.1)$ & $1.4(2.1)$ \\
\hline & Spearman's rho & Spearman's rho \\
\hline $\begin{array}{l}\text { Number of people in the } \\
\text { household }\end{array}$ & 0.032 & -0.001 \\
\hline $\begin{array}{l}\text { Family Adjustment } \\
\text { Problems Index }\end{array}$ & $0.39^{* * *}$ & $0.31^{* * *}$ \\
\hline $\begin{array}{l}\text { Peers Engaged in Risk } \\
\text { Behavior }\end{array}$ & $0.43^{* * *}$ & $0.29^{\star \star \star}$ \\
\hline $\begin{array}{l}\text { Number of years behind in } \\
\text { school }\end{array}$ & 0.066 & $0.15^{\star *}$ \\
\hline
\end{tabular}

and experienced $(71 \%)$ violence. ${ }^{31}$ However, the study used an instrument with a broader coverage of violence types and also inquired about lifetime exposure, in contrast with the current study's more restricted list of items and time frame of 12 months. However, two studies were identified that did use the same measure reported in the current study. Schwab-Stone et al. examined exposure to violence in a large sample $(n=2,600)$ of adolescents in an American urban center with high levels of economic disadvantage. The authors reported that $36 \%$ of the sample had suffered at least one of the six types of violence investigated. ${ }^{26}$ Ruchkin et al. examined the levels of violence in a sample of 370 delinquent youth within a juvenile detention center in northern Russia and found violence exposure rates of 50\% (witnessed) and $32 \%$ (experienced). ${ }^{3}$ The higher rates found in the present study in relation to Russia's may be partly due to the difference in the overall level of violence in the two countries, as indicated by homicide rates. Based on data from the 1990s, the homicide rate in Brazil was 32 deaths per 100,000 inhabitants, whereas in Russia it was nearly half of that, with 18 deaths per $100,000 .{ }^{32}$ Furthermore, the study settings were different in these two countries, with São Paulo being a large urban centre in contrast with the northern Russian district studied.

Few gender differences were found in this study, specifically in the areas of exposure to violence and physical abuse. Although some studies have obtained similar findings - for example, in the case of youth recruited from a poor, urban community in the United States with high crime rates ${ }^{33}$ - most investigations found boys to be more exposed to community violence as compared with girls. ${ }^{14,33,34}$ As these studies covered a number of community and higher risk samples, thus implying the robustness of this gender-related pattern, the question is raised about why a similar pattern was not observed in the current findings. Conduct disorder, which substantially overlaps with the construct of delinquency, is much less frequent in girls than in boys. ${ }^{35}$ Girls with conduct disorder may represent a more extreme subset within this gender group in contrast with boys. This more extreme group may then have similar or even more extreme experiences than their male counterparts. Supporting this is the finding that more girls than boys in this sample had slept on the street, a particularly extreme experience.

The current study found higher rates of sexual abuse among girls compared with boys. This is consistent with findings from both community and incarcerated samples of girls. ${ }^{14,16,18}$ Although smaller in number, the extent of exposures and the higher rates of sexual abuse require that policies and interventions aimed at reducing the exposure to violence of youth at risk for delinquency and incarceration give special attentions to girls.

Family adjustment problems figured prominently among the correlates of both witnessed and experienced violence in the final regression models of the analysis. This was partially consistent with findings by Salzinger et al., which found that family problems mediated the risk of exposure to community violence in a sample from New York City. ${ }^{11}$ Similarly, a separate investigation examined the rates of exposure to community violence among youth across 
Table 4 - Multiple hierarchical regression analyses identifying significant associated factors with witnessed and experienced violence

\begin{tabular}{|c|c|c|c|c|c|}
\hline Dependent variable & Block & Variable & $\beta$ & $\operatorname{Adj}^{2}$ & $\Delta \mathbf{R}^{2}$ \\
\hline \multirow[t]{9}{*}{ Witnessed violence } & 1. Demographic & Age & $-0.15^{* * *}$ & 0.016 & $0.020^{*}$ \\
\hline & \multirow[t]{2}{*}{ 2. Family problems } & Alcohol-related problems in family member & 0.035 & 0.173 & $0.162^{* * *}$ \\
\hline & & Family adjustment problems index & $0.21^{* * *}$ & & \\
\hline & \multirow{3}{*}{$\begin{array}{l}\text { 3. Peer group / } \\
\text { neighborhood }\end{array}$} & Peers engaged in risk behavior & $0.24^{\star \star \star}$ & 0.274 & $0.108^{* * *}$ \\
\hline & & Gang involvement & -0.007 & & \\
\hline & & Easy access to guns & $0.14^{*}$ & & \\
\hline & 4. Adverse experiences & Sleeping on the street & 0.09 & 0.285 & $0.014^{*}$ \\
\hline & \multirow[t]{2}{*}{ 5. Behavior problems } & Heavy drug use (youth) & 0.10 & 0.304 & $0.023^{*}$ \\
\hline & & Previous juvenile justice measure(s) & $0.12^{*}$ & & \\
\hline \multirow{9}{*}{$\begin{array}{l}\text { Experienced } \\
\text { violence }\end{array}$} & 1. Demographic & Age & -0.088 & 0.007 & 0.011 \\
\hline & 2. Family problems & Family Adjustment Problems Index & $0.20^{* * *}$ & 0.119 & $0.115^{* * *}$ \\
\hline & \multirow{3}{*}{$\begin{array}{l}\text { 3. Peer group / } \\
\text { neighborhood }\end{array}$} & Peers engaged in risk behavior & 0.093 & 0.155 & $0.045^{* * *}$ \\
\hline & & Gang involvement & 0.10 & & \\
\hline & & Easy access to guns & 0.052 & & \\
\hline & 4. Adverse experiences & Sleeping on the street & $0.14^{*}$ & 0.179 & $0.026^{* * *}$ \\
\hline & \multirow[t]{2}{*}{ 5. Behavior problems } & Heavy drug use (youth) & 0.070 & 0.188 & 0.015 \\
\hline & & Previous juvenile justice measure(s) & 0.094 & & \\
\hline & 6. School problems & Years behind in school & 0.039 & 0.186 & 0.001 \\
\hline
\end{tabular}

${ }^{*} p<0.05,{ }^{* *} p<0.01,{ }^{* * *} p<0.005$

different community settings and found the highest rates among youth from families that are economically struggling to survive (characterized, for example, by little cohesion and monitoring by parents) living in inner-city dwellings. ${ }^{12}$ Although the related variable "living arrangement" (e.g., not living with both parents) has been previously reported to be a predictor of exposure to violence, ${ }^{36}$ it was not a significant correlate in this study. A possible explanation for this is that not living with both parents is also frequent among the general population in Brazil. For instance, only $62.7 \%$ of eighth-graders in the city of São Paulo live with both biological parents. ${ }^{23}$

The correlates of violence include the household but extend beyond, into the neighborhood and broader social milieu. Among these additional risk factors, the variables peer group and neighborhood problems were among the most robust variables associated with exposure to violence; in particular, connection with high-risk peers was found to be strongly associated with witnessed violence. In a longitudinal study on the exposure of young adolescents to violence in high-risk neighborhoods, deviant behavior of friends, in conjunction with other risk factors, made an important contribution to the total exposure to violence one year later. ${ }^{11}$ Gun access by the youth may incorporate an additional dimension of risk, when combined with other contextual factors, to the prediction of exposure to violence. Though easy gun access by the youth uniquely contributed to witnessed violence levels, it proved redundant in the final model for experienced violence. Some reports suggest that weapon carrying may be associated with higher levels of witnessed violence, at least among high-risk youth. ${ }^{37}$ Likewise, the role of perpetration of violence or other criminal acts should be considered. Variables associated with behavior problems, particularly previous involvement with the juvenile justice system, were associated with witnessed violence in the multiple regression analysis, but not with experienced violence. This pattern was consistent with that found by Albus, Weist, and Perez-Smith in a cross-section of inner-city youth. ${ }^{38}$ Another study found the youth's own deviant behavior acts along with peer deviance to mediate the effects of problematic parenting on exposure to violence one year later. ${ }^{11}$ In general, the combination of these types of variables in the prediction of exposure to violence, i.e., involvement with high-risk peers, access to guns, and some direct involvement in criminal activities, is akin to the findings of Halliday-Boykins and Graham. ${ }^{39}$ These investigators describe how youth's general involvement with violence might underlie the associations between exposure to and perpetration of violence, as well as contribute to other undesirable outcomes such as connection with deviant peers. Violent crimes, predominantly robbery, were by far the most frequently self-reported index crime precipitating incarceration in this sample. ${ }^{24}$ Unfortunately, details concerning the perpetration of violent acts by the participants and the temporal relationship between this and exposure to violence were not available in this study.

The experience of sleeping on the street was also a significant correlate on both witnessed and experienced violence. Sleeping on the street alone may increase exposure to violence by virtue of the increased time spent on the street, where violence occurs. In addition, sleeping on the street is likely to be associated with other risk factors that may contribute to the youth's exposure to community violence (e.g., domestic violence, limited social networks). This finding strengthens the importance of prioritizing policies and interventions aimed at supporting youth at risk of living on the street or currently on the street. 
Unexpected was the finding that younger youth (aged 12 to14 years) reported higher exposure rates to witnessed and experienced violence, and this remained true in the multivariate model for witnessed violence. One possible explanation for this pattern is a sampling limitation, i.e., two of the male compounds were excluded from the sampling due to the heightened risk to staff. These compounds tended to house older and more recidivistic youth, who may in turn have had more exposure to violence. Therefore, older male youth included in this study may have had less extreme experiences than older male youth excluded from this study. Additionally, being incarcerated at a younger age may be indicative of a particular group exposed to extreme life experiences.

\section{Limitations}

First, these data are cross-sectional and sequencing of risks and exposure to violence cannot be determined from these data, nor can causality. Second, the examination of gender differences may have been limited by the relatively small size of the sample of girls. Third, sampling limitations, in particular the lack of sampling of some compounds that were more likely to house older and more recidivistic male youth may have resulted in a failure to sample a more representative range of the incarcerated population. It is not known whether the findings presented here can be generalized to populations other than incarcerated youth from the city of São Paulo; however, we are not aware of any peculiarities of this population that could prevent the generalization of the findings to other incarcerated populations in Brazil. Lastly, this study was not able to investigate the relationship between exposure to violence and violence perpetration by youth.

\section{Conclusion}

This study contributes to the growing recognition that delinquent youth are frequently exposed to very high rates of violence. Although most research has focused on youth from high-income countries, there is growing evidence that youth in low- and middle-income countries experience similar, if not more extreme, situations. These reports clearly identify a failure in the realization of the rights for protection of vulnerable youth under the UN Convention. Future research should investigate the effectiveness of strategies aimed at reducing high-risk youth's exposure to violence and improving the realization of their rights.

\section{Funding}

Dr. McLennan and Dr. Bordin received funding for the full study, including all aspects of data collection for the original study by the Canadian International Development Agency through the Child Protection Research Fund.

\section{Disclosures}

\begin{tabular}{|c|c|c|c|c|c|c|c|}
\hline $\begin{array}{l}\text { Writing group } \\
\text { member }\end{array}$ & Employment & $\begin{array}{l}\text { Research } \\
\text { grant }^{1}\end{array}$ & $\begin{array}{c}\text { Other research grant } \\
\text { or medical continuous } \\
\text { education }^{2}\end{array}$ & $\begin{array}{l}\text { Speaker's } \\
\text { honoraria }\end{array}$ & $\begin{array}{l}\text { Ownership } \\
\text { interest }\end{array}$ & $\begin{array}{l}\text { Consultant/ } \\
\text { Advisory } \\
\text { board }\end{array}$ & Other ${ }^{3}$ \\
\hline Susan Huculak & $\begin{array}{c}\text { University of } \\
\text { Calgary }\end{array}$ & - & - & - & - & - & - \\
\hline $\begin{array}{l}\text { John D. } \\
\text { McLennan }\end{array}$ & $\begin{array}{l}\text { University of } \\
\text { Calgary }\end{array}$ & $\begin{array}{l}\text { Canadian } \\
\text { International } \\
\text { Development } \\
\text { Agency } \\
\text { through the } \\
\text { Child } \\
\text { Protection } \\
\text { Research } \\
\text { Fund }\end{array}$ & - & - & - & - & - \\
\hline $\begin{array}{l}\text { Isabel A. S. } \\
\text { Bordin }\end{array}$ & UNIFESP & $\begin{array}{l}\text { Canadian } \\
\text { International } \\
\text { Development } \\
\text { Agency } \\
\text { through the } \\
\text { Child } \\
\text { Protection } \\
\text { Research } \\
\text { Fund }\end{array}$ & - & - & - & - & - \\
\hline
\end{tabular}

*Modest

${ }^{* *}$ Significant

***Significant. Amounts given to the author's institution or to a colleague for research in which the author has participation, not directly to the author. Note: UNIFESP = Universidade Federal de São Paulo.

For more information, see Instructions for Authors. 


\section{References}

1. UN General Assembly. Convention on the Rights of the Child, United Nations, Treaty Series. 1989;1577: 3. [cited 2010 aug 22]. Available from: http://www. unhcr.org/refworld/docid/3ae6b38f0.html.

2. Gorman-Smith D, Tolan P. The role of exposure to community violence and developmental problems among inner-city youth. Dev Psychopathol. 1998;10(1):101-16.

3. Ruchkin VV, Schwab-Stone M, Koposov R, Vermeiren R, Steiner H. Violence exposure, posttraumatic stress, and personality in juvenile delinquents. J Am Acad Child Adolesc Psychiatry. 2002;41(3):322-9.

4. O'Keefe M. Adolescents' exposure to community and school violence: prevalence and behavioural correlates. J Adolesc Health. 1997;20(5):368-76.

5. Buka SL, Stichick TL, Birdthistle I. Earls FJ. Youth exposure to violence: Prevalence, risks, and consequences. Am J Orthopsychiatry. 2001;71(3):298-310. 6. Aisenberg E, Herrenkohl T. Risk and resilience in children and families. $J$ Interpers Violence. 2008;23(3):296-315.

7. Paula CS, Vedovato MS, Bordin IAS, Barros MG, D'Antino ME, Mercadante MT. Mental health and violence among sixth grade students from a city in the state of São Paulo State. Rev Saude Publica. 2008;42(3):1-4. 8. Bailey S, Whittle N. Young people: victims of violence. Curr Opin Psychiatry. 2004;17(4):263-8.

9. Saltzman W, Pynoos R, Layne C, Steinberg A, Aisenberg E. Trauma/grieffocused intervention for adolescents exposed to community violence: Results of a school-based screening and group treatment protocol. Group Dyn-Theory Res Pract. 2001;5(4):291-303.

10. Eitle D, Turner RJ. Exposure to community violence and young adult crime: The effects of witnessing violence, traumatic victimization, and other stressful life events. J Res Crime Delinq. 2002;39(2):214-37.

11. Salzinger S, Ng-Mak DS, Feldman RS, Kam C, Rosario M. Exposure to community violence: Processes that increase the risk for inner-city middle school children. J Early Adolesc. 2006;26(2):232-66.

12. Sheidow AJ, Gorman-Smith D, Tolan PH, Henry DB. Family and community characteristics: Risk factors for violence exposure in inner-city youth. $A m J$ Community Psychol. 2001;29(3):345-60.

13. Weist MD, Acosta, OM, Youngstrom EA. Predictors of violence exposure among inner-city youth. J Clin Child Psychol. 2001;30(1):187-98.

14. Hanson RF, Self-Brown S, Fricker-Elhai A, Kilpatrick DG, Saunders BE, Resnick HS. Relations among family environment and violence exposure among youth: findings from the National Survey of Adolescents. Child Maltreat. 2006;11(1):3-15.

15. Nofziger S, Kurtz D. Violent lives: A lifestyle model linking exposure to violence to juvenile violent offending. J Res Crime Delinq. 2005;42(1):3-26.

16. Rosario M, Salzinger S, Feldman RS, Ng-Mak DS. Community violence exposure and delinquent behaviors among youth: The moderating role of coping. J Community Psychol. 2003;31(5):489-512.

17. Pallitto CC, Murillo V. Childhood abuse as a risk factor for adolescent pregnancy in El Salvador. J Adolesc Health. 2008;42(6):580-6.

18. Wood J, Foy DW, Layne C, Pynoos R, James CB. An examination of the relationships between violence exposure, posttraumatic stress symptomatology, and delinquent activity: An "ecopathological" model of delinquent behavior among incarcerated adolescents. J Aggression Maltreatment Trauma. 2002;6(1):127-47.

19. Abram KM, Teplin LA, Charles DR, Longworth SL, McClelland GM, Dulcan MK. Posttraumatic stress disorder and trauma in youth in juvenile detention. Arch Gen Psychiatry. 2004;61(4):403-10.

20. UNICEF. Making child rights constitutional in Brazil; 2001. [cited 2010 aug 23]. Available from:http://www.unicef.org/sowc96/lbrzil.htm.

21. Bochenek M, Delgado F. Children in custody in Brazil. Lancet. 2006;367(9511):696-7.

22. Amnesty International. Brazil A waste of lives: FEBEM juvenile detention centres, São Paulo. A human rights crisis, not a public security issue; 2000. AI Index: AMR 19/014/2000.

23. Instituto Brasileiro de Geografia e Estatística - IBGE. Pesquisa nacional de saúde do escolar. 2009. [citado 23 ago 2010]. Available from: http://www.ibge.gov.br/ home/estatistica/populacao/pense/pense.pdf
24. McLennan J, Bordin I, Bennett K, Rigato F, Brinkerhoff M. Trafficking among youth in conflict with the law in São Paulo, Brazil. Social Psych Psych Epid. 2008;43(10):816-23.

25. Weissberg RP, Voyce CK, Kasprow WJ, Arthur M, Shriver T. The social and health assessment. New Haven (CT); 1991.

26. Schwab-Stone M, Chen C, Greenberger E, Silver D, Lichtman J, Voyce C. No safe haven. II: The effects of violence exposure on urban youth. J Am Acad Child Adolesc Psychiatry. 1999;38(4):359-67.

27. Huculak S, McLennan JD. "The Lord is my Shepherd": Examining spirituality as a protection against mental health problems in youth exposed to violence in Brazil. Ment Health Religion Culture. 2010;13(5):467-84.

28. Associação Brasileira de Empresas de Pesquisa - ABEP. Critério de classificação econômica Brasil; 2003. [citado 23 ago 2010]. Available from:http://www.abep. org/codigosguias/ABEP_CCEB_2003.pdf.

29. Tarter RE, Kirisci L. Validity of the drug use screening inventory for predicting DSM-III-R substance use disorder. J Child Adoles Subst. 2001;10(4):45-53.

30. De Micheli D, Formigoni M. Psychometric properties of the Brazilian version of the drug use screening inventory. Alcohol Clin Exp Res. 2002;26(10):1523-8.

31. Zavaschi ML, Benetti S, Polanczyk GV, Soles N, Sanchotene ML. Adolescents exposed to physical violence in the community: a survey in Brazilian public schools. Rev Panam Salud Publica. 2002;12(5):327-32.

32. Krug E, Dahlberg LL, Mercy JA, Zwi AB, Lozano R, editors. World report on violence and health. Geneva, Switzerland: World Health Organization; 2002.

33. Foster JD, Kuperminc GP, Price AW. Gender differences in posttraumatic stress and related symptoms among inner-city minority youth exposed to community violence. J Youth Adolesc. 2004;33:59-70.

34. Ruchkin VV, Henrich CC, Jones SM, Vermeiren R, Schwab-Stone M. Violence exposure and psychopathology in urban youth: the mediating role of posttraumatic stress. J Abnorm Child Psychol. 2007;35(4):578-93.

35. Nock MK, Kazdin AE, Hiripi E, Kessler RC. Prevalence, subtypes, and correlates of DSM-IV conduct disorder in the National Comorbidity Survey Replication. Psychol Med. 2006;36(5):699-710.

36. Esbensen F, Huizinga D. Victimization and Delinquency. Youth Soc. 1991;23(2):202-28.

37. Patchin JW, Huebner McCluskey JD, Varano SP, Bynum TS. Exposure to community violence and childhood delinquency. Crime Delinquency. 2006;52(2):307-32.

38. Albus KE, Weist MD, Perez-Smith AM. Associations between youth risk behavior and exposure to violence: implications for the provision of mental health services in urban schools. Behav Modif. 2004;28(4):548-64.

39. Halliday-Boykins CA, Grahman S. At both ends of the gun: testing the relationship between community violence exposure and youth violent behaviour. J Abnorm Child Psychol. 2001;29(5):383-402. 